\title{
English Language Needs for Medical Students: A Link and Match of Academic and Professional Career
}

\author{
Sri Wahyuni \\ Universitas Baiturrahmah \\ sriwahyunizukhri31@gmail.com
}

\begin{abstract}
The objective of this study was to link and match the needs for an academic and professional career for medical students. The rationale is what English skills and communicative needs are learned at university should meet their needs in accomplishing their study and in pursuing their professional career. It is strongly believed that this link and match makes learning English take place. To achieve the aim of this study, descriptive analysis was used to analyze questionnaire responses. The questionnaires were distributed to 156 medical students of Baiturrahmah university who enrolled at Bahasa Inggris 6 course and had already passed Bahasa Inggris 1 to 5 courses. The finding indicated that $94,8 \%$ of medical students viewed that English was undoubtedly required for both academic and professional careers with listening and speaking skills as a priority. For medical needs, students viewed listening $(82,27 \%)$ and speaking $(82,21 \%)$. For professional needs, they believed listening $95.99 \%$ and speaking (85.25\%) were the priority. Interestingly, for academic needs, medical students needed communicative skills and strategies for reading English journal articles to finish their studies. For a professional career, participating in international seminars was in demand. By the study, it is strongly assumed that accommodating this link and match will make studying English more meaningful and beneficial.
\end{abstract}

Keywords: English Language, Needs, Link, and Match. 


\section{INTRODUCTION}

In the medical science context, English plays a very crucial role in medical studies as EMP (English for Medical Purposes). The EMP paves the way for medical students to read English medical textbooks and journal articles (Vahdany and Gerivani, 2016). The needs of English for medical students are not only for studying their subject matters but also for pursuing careers in the future (Niazi, 2012). Unquestionably, English is undoubtedly essential in medical settings for academic and professional purposes.

Those two purposes, academic and professional careers, have been identified by some studies by EMP researchers. For academic needs, scientific resources and technical terms of medicine use English, for example, medical English articles, books, research reports (Budianto, 2004). When someone wishes to be able to speak, read and write in fluent English, they must first have solid English language abilities (Apriani \& Anshori, 2019). For professional setting needs, Master (2005) found that interactions in conferences or other medical communities need English language skills. Ferguson (2013) identified that to be professionals, doctors need to communicate concerning medical needs, such as reading and writing case reports and letters of referral which English formats are already available. On the pave to be more professional in a career, doctor- foreign patient communication takes place in English (Basturkmen, 2010). Those studies stress the importance of English for medical purposes both academic and professional needs.

At the Medical Faculty of Baiturrahmah University, English is learned for specific purposes, that is, English for medical purposes (EMP) which is essential for the academic and professional needs of medical students. It is assumed that these two needs if accommodated well, will pave medical students' ways to accomplish their studies and to have an expected career. Thus, Need Analysis (NA) on what English needs are demanded their academic and professional career settings are identified in this article. 


\section{THEORETICAL FRAMEWORK}

\section{Needs for Medical EMP Students}

NA is an important stage in designing English for EMP materials (Belcher, 2006; (Nalini Arumugam, 2011); (Astika, 2015); (Alqurashi, 2016); (Aniqoh, 2018). Due to the importance of need analysis for EMP students, several research has been carried out with different findings in the context of English as a foreign language.

Budianto (2004) conducted a study aimed at identifying the most fundamental needs of the medical students in learning English at the medical faculty of Muhammadiyah University of Malang (MUM). The findings of his study revealed that $75 \%$ of respondents explained that they needed the materials relevant to their study and $25 \%$ of respondents explained that they needed speaking of writing and reading skills for their future careers.

Vahdany and Vahdany (2016) did a study intending to find out the English language needs of Medical students and General Practitioners in an EFL context at Guilan University of Medical Sciences, Iran. Their findings of the study showed that both medical students and General Practitioners valued reading skills, higher than the other language skills followed by writing skills. However, speaking skills had the least significance for both groups. And also, General practitioners reflected higher needs towards the English language than medical students.

The studies above reveal that need analysis (NA) is highly required at different places. The most important result is the bridge between what is taught at university and what is demanded in a professional career.

\section{The English Academic Needs for EMP Students}

As the English language has a considerable role in medical education, some studies have been conducted to find out English language needs for medical students in EFL (English as a Foreign Language) contexts. Some research was conducted due to the demand of conveying scientific, technological, and academic information globally expressed in English (Creswell, 2013). Thus, the use of medical English in seminars, textbooks, and journal articles has increased (Pavel, 2019); (Vera-Cazorla, 2015), thus suitable course contents for English must be carefully selected (Javid, 2011) and updated (Vera-Cazorla, 2015) . The 
need for research on the English language for academic purposes is highly demanded as indicated by some research findings.

There are varieties of the needs of English for academic settings. Studies conducted by Faraj (2015) to Libyan medical students and Piroozan, et.al, (2016) to Iranian medical students indicated that medical students' needs were to understand lectures, reading medical textbooks and journal articles, presenting articles, and getting actively involved in conferences. Furthermore, Muhammad, et.al. (2018) conducted a study for Arabian medical students who study English as a Foreign Language. Their findings showed that English was used in a variety of academic activities, such as lecturing, discussing medical issues, participating in seminars and conferences, reading articles and journals, comprehending graphs and charts, writing laboratory reports, essays, and research papers. These findings proved that that English was highly required in a variety of academic activities.

English is crucial to accomplish their study. There are a variety of activities that demand English as the medium to get knowledge and to actualize the knowledge of medicine written and orally. Understanding lectures, reading medical textbooks (Kayaoğlu \& Akbaş, 2016) and journal articles, and comprehending graphs and charts are some activities to get knowledge. While presenting articles and getting actively involved in conferences, discussions on medical issues, and writing laboratory reports, essays and research papers are examples of activities that use English for knowledge actualization. (Nhan et al., 2016) highlighted that teaching English for medical students need to prioritize reading, listening, speaking, and writing for knowledge actualization. In sum, English is essential for acquiring and communicating knowledge on medicine.

\section{The English Professional Career Needs for EMP Students}

This significantly demanded English for medical students' careers has been studied by some researchers. The aim of studies conducted is for medical students to learn English at university. The medical English learned, of course, deals with the sub-skills and topics needed (Nataša Milosavljević , Aleksandar Vuletić, 2015). (Poedjiastutie \& Puspitasari, 2019) found out from their study that English adds doctors to have better performance in their professional setting as doctors. Therefore, some studies, especially in EFL contexts, have been carried out with the end objectives on medical students' future needs. 
Budianto (2004) conducted a study on 36 students of the medical faculty of Muhammadiyah University of Malang (MUM), Indonesia about the use of English. The finding indicated that 18 respondents (50\%) responded that they used speaking skills most. Another 18 respondents (50\%) confirmed that they used reading skills too. Interestingly, none of them claimed that they would use English for writing and listening. In short, this finding stresses the importance of English speaking and reading skills for medical students.

Muhammad, et.al. (2018) in their study of Arabian medical students found out that learning medical English which was linked and matched to professional English is very crucial. Their findings listed the workplace demands of English. English was needed for participation in seminars, comprehension of English medical literature, manuals of medical equipment, and communication with foreign patients, doctors, and other health professionals. Other needs were to write medical purpose letters and medical prescriptions and to take case histories.

In conclusion, those studies revealed that in workplaces, English is for communication, especially speaking. Communicative activities like participating in international seminars and communicating with foreign patients need English speaking skills. Other needs of English, reading English medical literature, and understanding the manuals of medical equipment, are examples of activities requiring English reading skills (Antic, 2007) ; (Mcfarland, 2009) ; (Lodhi et al., 2018) .

At the Medical Faculty of Baiturrahmah University, English is learned for specific purposes, that is, English for medical purposes (EMP) which is essential for academic and professional needs for medical students. These two needs, if accommodated well, will pave their ways to accomplish their study and career. Thus, what English needs are required for their academic purposes and what is demanded at workplaces needs to be searched.

Hence, picturing English communicative needs for the Medical Faculty of Baiturrahmah University is crucial. The findings of this study can be for the development of appropriate English language contents which link and match between academic and career needs. It is important to view from different perspectives that can be valuable contributions to have appropriate links and match. 


\section{RESEARCH METHODOLOGY}

This descriptive study collected information on English language skills needed by medical students for academic needs and professional career needs. The respondents were 156 medical students who had already enrolled in Bahasa Inggris 1 to 4 courses. The data were collected by questionnaires written in the google form. The first section was about the importance of English and the priority of the English skills needed. The second section was about the needs of English for academic settings. The last section was about the need for English for a career.

It is important to note that the questionnaires were adapted from Vahdany and Gerivani (2016) as this study was carried out with similar purposes and characteristics of participants, that is, medical students. Experts' opinions were also obtained by responding to the expert validation questionnaire whether or not the questionnaire given to the students was readable, understandable, relevant, and applicable. Reliability was analyzed by SPSS 16 . The overall results indicated that the Cronbach's Alpha of measurement $(0,960)$ indicated that all items were reliable.

\section{FINDINGS AND DISCUSSION}

\section{FINDINGS}

The Importance of English Communicative Needs for EMP Students in Academic Settings.

Students' responses on the needs of English for medical students for academic settings were displayed from five questions.

\section{Is English important in your study?}

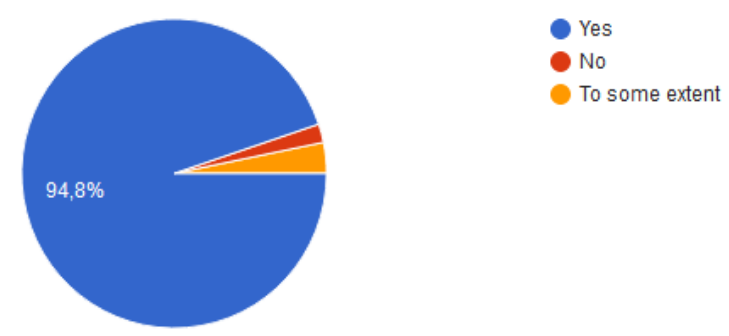

Chart 1. The Important of English 
From the chart above, it is clear that English is an extremely important factor in students' success in their medical program. 147 students $(94,8 \%)$ believed that English was the crucial important factor to determine their success at university. 3 students $(1,9 \%)$ thought that it was not important. 5 students (3.2\%) were in doubt.

\section{Is English important for your future career?}

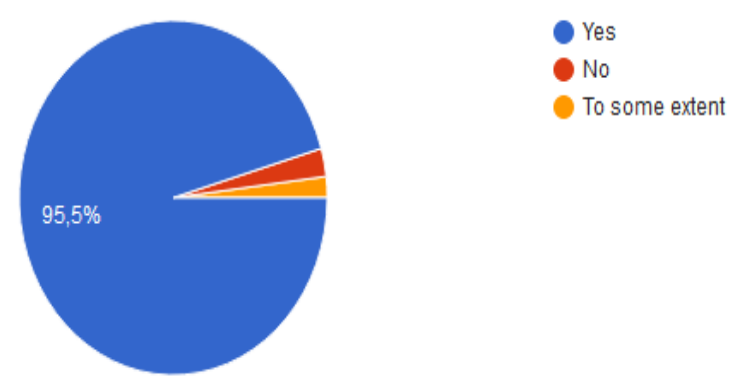

Chart 2. English for Your Future

This chart reveals that English is important for the student's future career as a medical professional. 149 students (95.5\%) believed that English was one of the important factors to a future career as a medical professional. 4 students $(2.6 \%)$ thought that it was not important. 3 students (1.9\%) were in doubt.

Do you agree that English is the only language of instruction in the classroom?

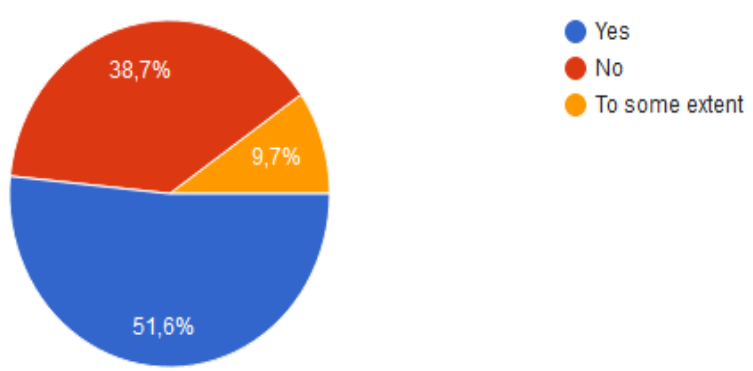

Chart 3. English is only Language Instruction 
This chart reveals that only half of the students agreed that the language used for classroom instruction was English. 80 students (51.6 $\%$ ) believed that English was the only language of instruction. 60 students $(38.7 \%)$ believed that it was not important. 15students (9.7\%) were in doubt.

Do you agree that professional English would be useful for your study?

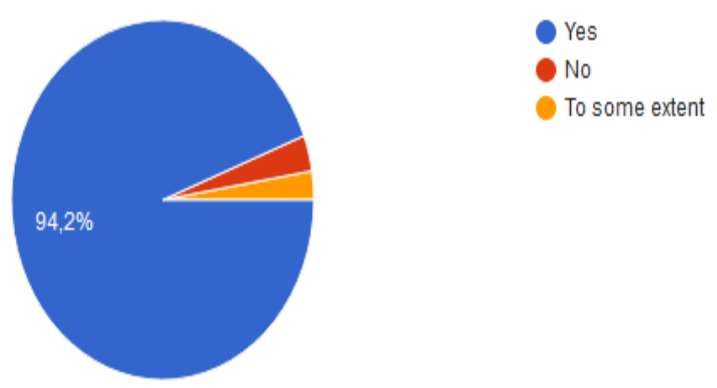

Chart 4. English Useful for Your Study

This chart shows that the majority of the students agreed to learn professional (Medical) English language would be useful in their medical studies. 146 students (95.2\%) believed that learning the medical English language helped them in their study. 5 students (3.2\%) thought that it was not important. 4 students (2.6\%) are in doubt.

\section{Which of the English language skills is the most important for your academic success at the university?}

The result shows that students agreed that listening was the most important followed by speaking than the other skills, reading, and writing. This strongly suggests that teaching and learning should be stressed on listening and speaking. English Language Communicative Needs for EMP Students in Academic Setting. The result also indicates that students placed the most important communicative English skill for the academic setting was that the skills or strategies to read articles and 
journals indicated by $82.05 \%$ of the degree of importance. The second importance was the skill to write research papers $(81.25 \%)$. The third one was the skill to follow lecture instructions $(80.60 \%)$. The others were the skills to discuss medical issues in seminars and conferences (79.96\%), to write essays and research papers $(79.64 \%)$, to comprehend graphs and charts (78.36\%), and to write laboratory reports $(77.40 \%)$.

\section{How important are the following English communicative needs of medical students academically?}

The chart reveals that participating in seminars (95.35\%) was the most important communicative English skill for professional careers. The second importance was the skill to read English medical literature $(83.33 \%)$. The third one was the skill to communicate with patients, doctors, and other health professionals from other countries $(82.53 \%)$. The others were to understand the manuals of medical equipment $(81.73 \%)$, to read case histories $(81.41 \%)$, to write medical prescriptions $(81.08 \%)$, and to write medical purpose letters $(79.32 \%)$.

\section{Which English skills are more important than the others at workplaces?}

The result shows that students agreed that listening was the most important followed by speaking than the other skills, reading, and writing. This finding indicated that in workplaces.

\section{DISCUSSION}

\section{The Importance of English and the Priority of the English Skills for EMP Students Academic Needs}

The majority of students view that English is in need both for their success at university and career. English is considered important for some reasons written by respondents on the Google form. First, English is an international language, therefore, some medical books are written in English, for example; journals, textbooks, drug labels, and manuals. Second, since English is spoken by more people in the world, it will be easier to communicate with foreign patients. Third, Google 
translate does not give us what we mean. Last, there are a lot of new medical updates about medicine in English. Clearly, English is highly demanded not only in studying but also in pursuing a medical career. Therefore, English courses play an important role for more medical students.

Questioning the idea of whether English can be used as the only language of instruction in all courses, not all of the respondents agree. Only 80 students $(51.6 \%)$ agree that English is the only language of instruction. 60 students (38.7\%) think that it is not important. 15 students $(9.7 \%)$ are in doubt. They think that Indonesian is easier to understand. They worry about their ability in English and the variety of English used by medical lecturers. This means that in the classroom, lecturers are demanded to mix the codes, Indonesian and English.

Students agree that listening and speaking skills need to be the focus of teaching and learning. Students view listening skills as extremely important (82.37\%) followed by speaking $82.21 \%$ for their success at university. As the needs of English for studying, they also view listening skill as extremely important (95.99\%) followed by speaking $(85.25 \%)$ for their success at workplaces. The needs of these listening and speaking skills can be seen clearly from the table below:

\section{Table 1.}

\section{The Importance of English}

\begin{tabular}{|l|l|l|}
\hline \multicolumn{1}{|c|}{ Skills } & \multicolumn{1}{|c|}{$\begin{array}{c}\text { Study } \\
\text { needs }\end{array}$} & \multicolumn{1}{c|}{$\begin{array}{c}\text { Career } \\
\text { need }\end{array}$} \\
\hline & $\%$ & $\%$ \\
\hline Listening & 82.37 & 95.99 \\
\hline Speaking & 82.21 & 85.25 \\
\hline Reading & 80.60 & 80.92 \\
\hline Writing & 78.20 & 78.20 \\
\hline
\end{tabular}




\section{English Language Communicative Needs for EMP Students for academic needs.}

Variety of English Language communicative needs are demanded by medical students. Reading articles and journals in English is the most important one indicated by $82.05 \%$ of the degree of importance. It is assumed that updating knowledge and issues in medicine are from periodical publications. Therefore, reading English articles and journals is necessary to be more professionals. The second importance is the skill to write research papers (81.25\%). The third one is that English is for following lecture instructions (80.60\%). English is demanded discussing medical issues in international seminars and conferences (79.96\%), writing essays and research papers (79.64\%), comprehending graphs and charts $(78.36 \%)$, and writing laboratory reports $(77.40 \%)$. The rank of the important communicative English skills can be revealed in the following table:

Table 2.

English Language Communicative Needs

\begin{tabular}{|l|l|c|}
\hline No & $\begin{array}{l}\text { Communicative English skills for } \\
\text { Academic Setting }\end{array}$ & \% \\
\hline & reading articles and journals & 82.05 \\
\hline & writing research papers & 81.25 \\
\hline & following lecture instructions & 80.60 \\
\hline & $\begin{array}{l}\text { discussing on medical issues in } \\
\text { seminars and conferences }\end{array}$ & 79.96 \\
\hline & writing essays and research papers & 79.64 \\
\hline & comprehending graphs and charts & 78.36 \\
\hline & writing laboratory reports & 77.40 \\
\hline
\end{tabular}

Those skills are highly demanded by the students in studying. These communicative skills underline why English is important in academic settings. They need skills or strategies to read articles and journals because a lot of medical resources are written in English. In addition, writing research papers in English is in need as students want to publish their research findings or ideas in international journals. The 
ability to actively participate in international seminars is important to update their knowledge on medicine.

\section{English Language Communicative Needs for EMP Students for Professional Career Needs.}

What communicative English skills are crucially viewed by medical students is identified by their responses. First, they believe that the most important communicative English skill for a professional career is the skill to participate in seminars (95.35\%). Second, reading medical literature published in the English language (83.33\%) is listed in the second one. Third, they also need the skill to communicate with foreign patients, doctors, and other health professionals (82.53\%). The other skills are to understand the manuals of medical equipment $(81.73 \%)$, to read case histories $(81.41 \%)$, to write medical prescriptions (81.08\%), and to write medical purpose letters $(79.32 \%)$. with the different levels of importance, it can be interpreted that all skills are viewed as important by medical students as none of the percentages is below $50 \%$.

To sum up, the four communicative English skills accommodate their needs in their career. To be professional in a career, the capability of listening and speaking is the key to having a good career. Participating in seminars, of course; needs listening, speaking, reading, and writing skills. To be actively involved in international seminars, the ability to speak English is a must. In addition, speaking is essential to communicate with many different colleagues and doctors across the world. Reading strategies are indeed crucial. English Reading ability helps them to understand more medical literature published in English, and this ability ends in updating medical knowledge. As the participants of this study believe that listening and speaking are their main concerns, reading and writing abilities are also highly demanded to be more professional doctors.

\section{CONCLUSION}

English taught for medical students does not only accommodate students' needs for studying but also their needs for being professional doctors. In this sense, the English that they learn can be strongly linked 
to their future working lives. It is strongly believed that with this link and match English subjects will be meaningful. If it is already meaningful, learning is assumed to take place. The findings of this study prove that English is unquestionably essential for medical students both in studying and having desirable careers in the future. The finding also indicates that students need listening and speaking skills more than reading and writing skills. To meet the needs, teaching materials and methods should focus on listening and speaking practices. Furthermore, medical students need strategies for reading articles and journals, writing research papers, and following lecture instructions that use English as a medium for communication. These needs should be well accommodated in teaching and learning syllabus and classroom activities. Like for academic needs, for a professional career participating in international seminars, reading English medical literature, and communicating with patients and other health professionals from many different countries are communicative English skills needed. The findings on the academic and career needs of medical students suggest that English should be integrated practiced with a heavy emphasis on listening and speaking as well as a variety of skills as proved by this study.

\section{REFERENCES}

Alqurashi, F. (2016). English for Medical Purposes for Saudi Medical and Health Professionals. Advances in Language and Literary Studies, 7(6). https://doi.org/10.7575/aiac.alls.v.7n.6p.243.

Aniqoh. (2018). Need Analysis of Esp Materials for the Medical Laboratory Technology Students in the Health Polytechnics Semarang. http://eprints.ums.ac.id/22572/14/NASKAH_PUBLIKASI_FINAL.pdf

Antic, Z. (2007). Forward in Teaching English for Medical Purposes. Medicine and Biology, 14(3), 141-147.

Apriani, E., Anshori, S., \& Edy, S. (2019). Eksistensi English Zone Sebagai Media Penerapan Kemampuan Berbahasa Inggris Mahasiswa Program Studi Tadris Bahasa Inggris IAIN CURUP. Cendekia: Jurnal Kependidikan Dan Kemasyarakatan, 17(2), 317-332. 
Astika, G. (2015). The Role of Needs Analysis in English for Specific Purposes. TEFLIN Journal - A Publication on the Teaching and Learning of English, 10(1), 31. https://doi.org/10.15639/teflinjournal.v10i1/31-47

Basturkmen, H. (2010). Developing courses in English for specific purposes. Basingstoke, UK: Palgrave/Macmillan

Belcher, D. D. (2006). English for Specific Purposes: Teaching to Perceived Needs and Imagined Futures in Worlds of Work, Study, and Everyday Life. TESOL Quarterly, 4O(1), 133. https://doi.org/10.2307/40264514

Budianto, Langgeng. (2004). Students' Needs in Learning English in the Medical Faculty of Muhammadiyah University at Malang. Jurnal Ilmu Pendidikan, Oktober 2004, Jilid 11, Nomor 3. retrieved from https://www.researchgate.net/publication _

Creswell, J. W. (2013). Qualitative Inquiry \& Research Design Choosing Among Five Approaches- 3/E.

Davies, W., Fraser, S., Lauer, J., Howell, P., デービスウォルター, フレイ ザーサイモン，ラウアージョー，＆ハハエルピーター. (2013). English for Medical Purposes : Teaching an Intensive English Course to Third-Year Medical Students. 広島外国語教育研究，16，49-64. http://ci.nii.ac.jp/naid/120005245553/

Faraj, B. M. A. (2015). English for medical education in EFL context. Journal of Teaching English for Specific and Academic Purposes, 3(1), 121-148.

Faraj, Basim M. Abubaker . (2015). English For Medical Education In Efl Context, The Journal of Teaching English For Specific And Academic Purposes Vol. 3, No 1, 2015, pp. 121-148. http://espeap.junis.ni.ac.rs.

Ferguson, G. (2013). English for medical purposes. In Paltridge, B., Starfield, S. Chichester (eds). The Handbook of English for Specific Purposes. Chichester: Wiley-Blackwell. 
Javid, C. Z. (2011). EMP Needs of Medical Undergraduates in a Saudi Context. Phys. Rev. E, 14, 89-110.

Lodhi, M. A., Shamim, M., Robab, M., Shahzad, S., \& Ashraf, A. (2018). English for Doctors: An ESP Approach to Needs Analysis and Course Design For Medical Students. International Journal of English Linguistics, 8(5), 205. https://doi.org/10.5539/ijel.v8n5p205

Master, P. (2005). Research in English for specific purposes. In E. Hinkel (ed.). Handbook of Research in Second Language Teaching and Learning (pp. 99-116). London: Lawrence Erlbaum Associates.

Mcfarland, J. (2009). Teaching English to the medical profession Developing communication skills and bringing humanities to medicine. X, 173-175.

Molhim, M. A. (2014). English for Medical Purposes Course Design for Arab University Students. https://www.scribd.com/document/220537502/English-for-MedicalPurposes-Course-Design-for-Arab-University-Students

Muhammad, et.al. (2018). English for Doctors: An ESP Approach to Needs Analysis and Course Design For Medical Students. International Journal of English Linguistics; Vol. 8, No. 5; 2018 ISSN 1923-869X E-ISSN 1923-8703, retrieved from https://www.researchgate.net/publication _

Nalini Arumugam, N. K. (2011). Needs analysis on the importance of english communication skills for medical assistants. Journal of Institutional Research South East Asia, 9(2), 1-75.

Nataša Milosavljević , Aleksandar Vuletić, L. J. (2015). Learning Medical English: A Prerequisite for Successful Academic and Professional Education.

Nezakatgoo, B. (n.d.). Assessing Task-based English Language Needs of Medicine Students : Are They Aligned with Pedagogical Tasks in EMS Courses? February 2014. 
Nhan, N. T., Debattista, J., Health, Q., \& Queensland, T. (2016). Medical Students Need a Core English Curriculum Based on Cefr ( Common European Framewor .... 4(January), 14-23.

Niazi, M. M. (2012). English for medical purposes: A case of English for Specific Purposes. National University of Modern Languages, Islamabad, Pakistan.

Pavel, E. (2019). Teaching english for medical purposes. January.

Piroozan, A., Boushehri, E., \& Fazeli, R. (2016). A review of English for medical purposes for Iranian EFL learners. Journal of Advances in English Language Teaching, 4(2), 24-29.

Poedjiastutie, D., \& Puspitasari, R. (2019). Do Doctors Need Communication in their Job Places? (A Case in Indonesia). IJEE (Indonesian Journal of English Education), 5(2), 127-142. https://doi.org/10.15408/ijee.v5i2.10134

Vahdany, Fereidoon and Gerivani, Leila. (2016). An Analysis of the English Language Needs of Medical Students And General Practitioners: A Case Study Of Guilan University of Medical Sciences. International Journal of English Language and Literature Studies 5(2): 104-110

Vera-Cazorla, M. J. (2015). An analysis of the textbooks for teaching English for medical purposes in the former Degree in Medicine at the University of Las Palmas de Gran Canaria. In Journal of English Studies (Vol. 13, p. 175). https://doi.org/10.18172/jes.2818 